\title{
Serum Glial Fibrillary Acidic Protein: A Surrogate Marker of the Activity of Multiple Sclerosis
}

\author{
Serum Gliyal Fibriler Asidik Protein: Multipl Skleroz Aktivitesinin \\ Temsili Bir Markörü
}

\author{
Inas K. SHARQUIE $\odot$, Gheyath AL GAWWAM $\odot$, Shatha F. ABDULLAH $\odot$
}

Ethics Committee Approval: This study was approved by the Scientific Ethic Committee of Collage
of Medicine, University of Baghdad, 8 July 2020, 1590 .
Conflict of interest: The authors declare that they have no conflict of interest.
Funding: None.
Informed Consent: Informed consent was taken from the patients enrolled in this study.
Cite as: Sharquie IK, Al Gawwam G, Abdullah SF. Serum glial fibrillary acidic protein: A surrogate marker of the activity of multiple sclerosis. Medeni Med J. 2020;35:212-8.

\begin{abstract}
Objective: Multiple sclerosis (MS) is a neurodegenerative disorder with various clinical types. Glial fibrillary acidic protein (GFAP) is significantly elevated in the cerebrospinal fluid (CSF) of MS patients compared with that of healthy controls. The aim of this study is to evaluate serum levels of GFAP in relation to disease activity in relapsing-remitting MS patients and to compare them with those of healthy controls.

Method: This study involved 58 MS patients of relapsing-remitting MS (RRMS) type, 22 in an active stage of the disease and 36 in remission, and 50 healthy individuals as age- and sexmatched controls. Blood samples were taken from the patients at the MS Clinic of the Baghdad Teaching Hospital, and the serum levels of GFAP were determined using the enzyme-linked immunosorbent assay (ELISA) technique.

Results: Mean GFAP serum levels in 22 patients presenting in the active state of the disease $(6.47 \pm 3.39 \mathrm{ng} / \mathrm{ml})$ and 36 cases in remission were $(5.33 \pm 2.82 \mathrm{ng} / \mathrm{ml})(p=0.074)$ were determined as indicated. When RRMS patients $(n=58)$ were compared with the healthy controls $(n=50$, $1.89 \pm 1.21)$, the difference in serum levels of GFAP was statistically significant $(p<0.001)$. The area under the curve of the serum measures of GFAP obtained through the receiver operating characteristics was 0.903, which was also statistically significant $(p<0.001)$.

Conclusion: GFAP biomarker is an indicator of disease activity in RRMS patients, and its serum level may correlate with the state of remission or exacerbation.
\end{abstract}

Keywords: Multiple sclerosis, remission, relapsing, serum glial fibrillary acidic protein, GFAP, RRMS

öz

Amaç: Multipl skleroz (MS), çeşitli klinik tipleri olan nörodejeneratif bir hastalıktır. Gliyal fibriler asidik protein (GFAP), MS hastalarının beyin omurilik sıvısında sağlıklı bireylere kıyasla önemli ölçüde yükselmiştir. Bu çalışmanın amacı, RRMS tipinde MS hastalarında hastalık aktivitesi ile ilişkili olarak serum GFAP düzeylerini değerlendirmek ve bunları sağlıkı bireylerle karşılaştırmaktır.

Yöntem: Bu çalışma, 22'si hastalığın aktif bir aşamasında ve 36'sı remisyonda olmak üzere toplam 58 RRMS tipinde MS hastası ile yaş ve cinsiyet uyumlu 50 sağlıklı bireyi kapsamaktadır. Bağdat Ĕgitim hastanesi MS Kliniğinde hastalardan kan örnekleri alınarak GFAP serum seviyeleri, enzime bağlı immünosorban testi (ELISA) kullanılarak belirlenmiştir.

Bulgular: GFAP serum seviyeleri, hastalığın aktif durumunda ( $n=22,6,47 \pm 3,39 \mathrm{ng} / \mathrm{ml})$, remisyonda olanlara $(n=36,5,33 \pm 2,82 \mathrm{ng} / \mathrm{ml})$ göre yükselmiştir $(p=0,214)$. RRMS hastaları $(n=58)$ sağlıklı bireyler $(n=50,1,89 \pm 1,21)$ ile karşılaştırıldığında GFAP'nin serum seviyelerindeki fark istatistiksel açıdan oldukça anlamlı bulunmuştur $(p<0,001)$. Alıcının çalışma karakteristiklerinden elde edilen GFAP serum ölçümlerinde, eğri altındaki alan 0,903 bulunmuştur ve bu değer istatistiksel olarak anlamlıdır ( $p<0,001)$.

Sonuç: GFAP biyobelirteci, RRMS hastalarında hastalık aktivitesinin bir göstergesidir ve serum seviyeleri remisyon veya alevlenme durumuyla ilişkili olabilir.

Anahtar kelimeler: Multipl skleroz, remisyon, tekrarlayan, serum glial fibriler asidik protein, GFAP, RRMS

( ) Copyright Istanbul Medeniyet University Faculty of Medicine. This journal is published by Logos Medical Publishing.

Licenced by Creative Commons Attribution-NonCommercial 4.0 International (CC BY-NC 4.0)
Received: 1 August 2020

Accepted: 12 September 2020 Online First: 30 September 2020

Corresponding Author: I.K. Sharquie

ORCID: 0000-0002-4953-7365 University of Baghdad, College of Medicine, Department of Microbiology \& Immunology, Baghdad, Iraq

iksharquie@yahoo.com inasksharquie@comed.uobaghdad. edu.iq

G. Al Gawwam

ORCID: 0000-0002-5614-7680 University of Baghdad, College of Medicine, Baghdad Teaching Hospital, Department of Neurology, Baghdad, Iraq

S.F. Abdullah

ORCID: 0000-0001-7963-5102 University of Baghdad, College of Medicine, Department of Microbiology \& Immunology, Baghdad, Iraq 


\section{INTRODUCTION}

Multiple sclerosis (MS) is an autoimmune neurodegenerative disease, affecting the central nervous system (CNS). This chronic disease is triggered by autoreactive inflammatory cells that cross the blood-brain barrier (BBB) and enter the CNS where they cause local damage that results in neuronal demyelination, asterogliotic scarring, and axonal dysfunction ${ }^{1}$. MS has been characterized by inflammatory lesions of caused by invasion with B- and T- lymphocytes' (CD4 and CD8) as well as activated macrophages ${ }^{2}$. The inflammatory infiltrates damage neurones in the spinal cord and brain causing discharge of debris, including structural proteins. Serum concentrations of the released proteins are directly proportional to the level of tissue damage and cellular death ${ }^{3}$.

Glial fibrillary acidic protein (GFAP) is the most important intermediate astrocytic cytoskeletal protein that plays a central role in the motility and morphology of astrocytes, in addition to the cellular interaction and functioning of the bloodbrain barrier ${ }^{4}$. It is the principal protein found in chronic MS lesions and is released into the cerebrospinal fluid (CSF) from damaged, degenerating brain cells or during traumatic brain injuries ${ }^{5}$. It can also be seen in the peripheral blood secondary to damage of the blood-brain barrier ${ }^{6,7}$. Elevated serum levels of GFAP can serve as a useful prognostic and diagnostic marker in the evaluation of several neurological diseases ranging from stroke to neurodegenerative disorders, for instance Alzheimer's disease ${ }^{8}$.

GFAP could serve as a potential neurodegenerative disease autoantigen. Because it was unexpectedly shown that $40 \%$ of the patients who have suffered a traumatic brain-injury demonstrated an autoantibody response to the protein?. High levels of GFAP in the CSF have also been linked with early progression to disabilities in patients suffering from $\mathrm{MS}^{10}$. This suggests that there is a direct correlation between GFAP concentration in the serum and $\mathrm{CSF}^{11}$. This being the case, GFAP serum levels could serve as a potentially useful biomarker for investigation in patients with active relapsing-remitting MS (RRMS) and also those in remission. GFAP release to the blood after brain cell damage may facilitate early diagnosis of MS and disease activity.

\section{MATERIAL and METHODS}

This cross-sectional study involved 58 individuals with RRMS. These patients were diagnosed according to the revised guidelines of the consortium of MS in $2018^{12}$. Clinical type of RRMS was determined according to the Lublin and Ringold classification ${ }^{13}$. The diagnoses of 36 patients with inactive RRMS, and 22 patients with active disease had been proven by the presence of new gadolinium-enhancing lesions and new symptoms including at least one relapse or attack (that means clinical symptoms continued more than 24 hours) in the preceding 24 months, although they were on treatment with Betaferon, Rebif, Avonex, Fingolimod and Natalizumab. All RRMS patients were identified in clinical remission as in the recovery period with no relapses or based on the MRI evidence of disease activity in the preceding 24 months before registration in the study.

The participants were recruited from the MS Clinic in the Department of Neurology, Baghdad Teaching Hospital. We also recruited 50 healthy adults to serve as a control group. All relevant patient data i.e. name, sex, age, and stage of disease were obtained from medical histories and clinical examinations. All patients gave consent to participate in the research after they were given full information regarding the nature of the study, as agreed by the Scientific Committee of Ethics at the University of Baghdad, College of Medicine. The ethics committee's approval number was 1590.

Serum samples were obtained from all partici- 
pants and then stored at $-20^{\circ} \mathrm{C}$. Serum GFAP levels were measured using a human GFAP ELISA kit (MyBioSource, USA) following the manufacturer's instructions. The samples were pipetted into a 96-well plate pre-coated with GFAP antibody and then incubated for 2 hours. After incubation, any unbound substances were removed, and the biotin-conjugated antibody specific for GFAP was added to the wells. Avidin-horseradish peroxidase conjugate was then added to the wells after washing the plate three times with buffer solution. The plates were incubated for an hour at $37^{\circ} \mathrm{C}$ before being washed five times with buffer to remove any unbound avidin-enzyme reagent. Finally, 3,3',5,5'-tetramethylbenzidine substrate was added to each well and the plate was incubated at $37^{\circ} \mathrm{C}$ for $15-30$ minutes. The development of colour in each well was recorded and found to be directly proportional to the amount of GFAP bound during the initial step. A plate reader set to $450 \mathrm{~nm}$ was used to determine the absorbance values.

\section{Statistical Analysis}

The SPSS statistical package (Version 20; SPSS, IBM) was used to perform statistical analysis. Microsoft Excel (2010) was used to produce all the figures except the receiver operating characteristic (ROC) curve. Quantitative variables, i.e. age and serum levels of GFAP, expressed as $n g / m L$, were compared between groups using the analysis of variance (ANOVA) F-test and the least significant difference (LSD) F-test. The normally distributed data were expressed as mean \pm standard deviation (SD). The Pearson chi-square test $\left(x^{2}\right)$ was used for the comparison of qualitative variables, i.e. age, gender and serum GFAP group, and the data were expressed as percentages. Validity of the ELISA test was established using the ROC curve, area under the curve (AUC), specificity (\%), sensitivity (\%), accuracy, negative predictive value (NPV, \%), and positive predictive value (PPV, \%). A p value of $<0.05$ was considered to be statistically significant.

\section{RESULTS}

Our study involved 58 RRMS patients, of whom 22 (six men and 16 women) presented with active disease. Patients' ages were between 25 and 63 years, with a mean age of $39.82 \pm 10.78$ years. The other 36 (14 men and 22 women) patients aged from 23 to 54 years and with a mean age of $34.22 \pm 8.98$ years, presented with inactive RRMS. The ages of the 50 ( 18 men and 32 women) healthy individuals recruited as controls ranged from 22 to 50 years, and their mean age was $33.96 \pm 7.31$ years. A comparison of the age data was conducted using ANOVA (F-test) and showed a statistically non-significant difference $(p=0.154)$, between active, inactive RRMS patients, and the healthy controls.

Comparison of active, inactive RRMS patients, and control subjects amongst their age groups yielded different results. In the age group of 20-40 years, smaller number of active RRMS patients $(n=10$, $45.5 \%$ ) and greater number of inactive RRMS patients $(\mathrm{n}=28,77.8 \%)$ and healthy control subjects $(n=32,64 \%)$ were detected.

In the age group of 41-60 years, increased number of active RRMS patients ( $n=12,54.5 \%)$, but smaller number of inactive RRMS patients $(n=8$, $22.2 \%)$, and healthy control subjects ( $n=18,36 \%)$. were noted. There was a significant difference between groups $(p=0.043$ ) (Table 1$)$.

In terms of gender, the majority of the active group of RRMS patients were female $(n=16,72.7 \%)$, compared to only six males (27.3\%). Amongst the patients with inactive RRMS, there was also a female predominance over males, i.e. 22 (66.1\%) and $14(38.9 \%)$, respectively. In the healthy control group, there were 32 women (66.1\%) and 18 men (36\%). Analysis of these results showed a statistically non-significant difference between genders of the patients $(p=0.812)$ (Table 1$)$.

Patients with active and inactive RRMS showed 
Table 1. A comparison of RRMS patients and healthy individuals by demographics.

\begin{tabular}{|c|c|c|c|c|c|c|}
\hline \multirow[b]{2}{*}{ Demographics } & & \multicolumn{2}{|c|}{ RRMS patients $n=58$} & \multirow[b]{2}{*}{$\begin{array}{l}\text { Healthy subjects } \\
n=50\end{array}$} & \multicolumn{2}{|c|}{ (P-value) } \\
\hline & & $\begin{array}{l}\text { Active } \\
\mathrm{n}=\mathbf{2 2}\end{array}$ & $\begin{array}{l}\text { Inactive } \\
\mathrm{n}=36\end{array}$ & & ANOVA test & LSD test \\
\hline $\begin{array}{l}\text { Age/Year } \\
(\text { Mean } \pm \text { SD) } \\
\text { SEM }\end{array}$ & & $\begin{array}{l}(39.82 \pm 10.78) \\
3.25\end{array}$ & $\begin{array}{l}(34.22 \pm 8.98) \\
2.12\end{array}$ & $\begin{array}{l}(33.96 \pm 7.31) \\
1.46\end{array}$ & $\begin{array}{l}\mathrm{P}=0.154 \\
\text { Non-significant }\end{array}$ & $\begin{array}{l}\mathrm{P}^{1}=0.097 \mathrm{NS} \\
\mathrm{P}^{2}=0.067 \mathrm{NS} \\
\mathrm{P}^{3}=0.922 \mathrm{NS}\end{array}$ \\
\hline $\begin{array}{l}\text { Age groups/Year } \\
\text { (n) } \%\end{array}$ & $\begin{array}{l}20-40 \\
41-60\end{array}$ & $\begin{array}{l}\text { (10) } 45.5 \% \\
(12) 54.5 \%\end{array}$ & $\begin{array}{l}\text { (28) } 77.8 \% \\
\text { (8) } 22.2 \%\end{array}$ & $\begin{array}{l}\text { (32) } 64 \% \\
\text { (18) } 36 \%\end{array}$ & $\begin{array}{l}\mathrm{P}=0.043 \\
\text { Significant }\end{array}$ & $\begin{array}{l}\mathrm{P}^{1}=0.012 \mathrm{~S} \\
\mathrm{P}^{2}=0.141 \mathrm{NS} \\
\mathrm{P}^{3}=0.171 \mathrm{NS}\end{array}$ \\
\hline & & & & & \multicolumn{2}{|c|}{$x^{2}$ test } \\
\hline $\begin{array}{l}\text { Gender } \\
\text { (n) } \%\end{array}$ & $\begin{array}{l}\text { Male }(M) \\
\text { Female }(F) \\
M / F \text { ratio }\end{array}$ & $\begin{array}{l}\text { (6) } 27.3 \% \\
(16) 72.7 \% \\
0.375\end{array}$ & $\begin{array}{l}(14) 38.9 \% \\
(22) 66.1 \% \\
0.636\end{array}$ & $\begin{array}{l}\text { (18) } 36 \% \\
(32) 64 \% \\
0.5625\end{array}$ & $\begin{array}{l}\mathrm{P}=0.659 \\
\text { Non-significant }\end{array}$ & $\begin{array}{l}\mathrm{P}^{1}=0.366 \mathrm{NS} \\
\mathrm{P}^{2}=0.469 \mathrm{NS} \\
\mathrm{P}^{3}=0.785 \mathrm{NS}\end{array}$ \\
\hline
\end{tabular}

Note: $p^{1}=$ Active vs. inactive, $p^{2}=$ Active vs. healthy donors, $p^{3}=$ Inactive vs. healthy donors, NS =Non-significant difference at $p$ values above 0.05, S=Significant difference at $p$ values below 0.05 , HS=Highly significant difference at $P$ values below 0.01 .

Table 2. A comparison of serum concentrations of GFAP ( $\mathrm{ng} / \mathrm{mL}$ ) between RRMS patients and healthy individuals.

\begin{tabular}{|c|c|c|c|c|c|c|}
\hline \multirow[b]{2}{*}{ Assay } & & \multicolumn{2}{|c|}{ RRMS patients $n=58$} & \multirow[b]{2}{*}{$\begin{array}{l}\text { Healthy subjects } \\
\mathrm{n}=50\end{array}$} & \multicolumn{2}{|c|}{ (P-value) } \\
\hline & & $\begin{array}{l}\text { Active } \\
\mathbf{n}=\mathbf{2 2}\end{array}$ & $\begin{array}{l}\text { Inactive } \\
\mathrm{n}=36\end{array}$ & & ANOVA test & LSD test \\
\hline $\begin{array}{l}\text { Serum GFAP } \\
\text { ng/mL } \\
(\text { Mean } \pm \text { SD) SEM }\end{array}$ & & $\begin{array}{l}(6.47 \pm 3.39) \\
1.022\end{array}$ & $\begin{array}{l}(5.33 \pm 2.82) \\
0.665\end{array}$ & $\begin{array}{l}(1.89 \pm 1.21) \\
0.24\end{array}$ & $\begin{array}{l}\mathrm{P}<0.001 \\
\text { Highly } \\
\text { significant }\end{array}$ & $\begin{array}{l}\mathrm{p}^{1}=0.074 \mathrm{NS} \\
\mathrm{p}^{2}<0.001 \mathrm{HS} \\
\mathrm{p}^{3}<0.001 \mathrm{HS}\end{array}$ \\
\hline Serum & Hyper & & & & & \\
\hline $\begin{array}{l}\text { GFAP } \\
\text { ng/mL } \\
\text { (cut-off }\end{array}$ & $\begin{array}{l}\text { (>cut-off) } \\
\text { Normal } \\
\text { (<cut-off) }\end{array}$ & $\begin{array}{l}\text { (20) } 90.9 \% \\
\text { (2) } 9.1 \%\end{array}$ & $\begin{array}{l}\text { (32) } 88.9 \% \\
\text { (4) } 11.1 \%\end{array}$ & $\begin{array}{l}\text { (12) } 24 \% \\
\text { (38) } 76 \%\end{array}$ & $\begin{array}{l}\mathrm{p}<0.001 \\
\text { Highly } \\
\text { significant }\end{array}$ & $\begin{array}{l}\mathrm{p}^{1}=0.806 \mathrm{NS} \\
\mathrm{p}^{2}<0.001 \mathrm{HS} \\
\mathrm{p}^{3}<0.001 \mathrm{HS}\end{array}$ \\
\hline
\end{tabular}

Note: $p^{1}=$ Active vs. inactive, $p^{2}=$ Active vs. healthy donors, $p^{3}=$ Inactive vs. healthy donors, NS =Non-significant difference at $p$ values above 0.05, $\mathrm{S}=$ Significant difference at $p$ values below 0.05 , HS=Highly significant difference at $p$ values below 0.01 .

a higher mean concentration of serum levels of GFAP, i.e. $6.47 \pm 3.39$ and $5.33 \pm 2.82 \mathrm{ng} / \mathrm{mL}$, respectively, than that of the healthy controls $(1.89 \pm 1.21 \mathrm{ng} / \mathrm{mL})$ and these results were highly significantly different $(p<0.001)$. Although a slight elevation in serum levels of GFAP was observed in active versus inactive RRMS patients, the difference was not statistically significant $(p=0.074)$ according to the LSD F-test.

Most patients with active RRMS had elevated serum levels of GFAP $(n=20,90.9 \%)$ and only two of them $(9.1 \%)$ showed normal levels below the cut-off value. Similar results were observed with inactive MS patients. Indeed, serum GFAP levels were increased in 32 (88.9\%) and within normal limits in $4(11.1 \%)$ inactive MS patients. While normal $(n=38,6 \%)$, and elevated $(n=12,24 \%)$ values of GFAP were detected in indicated number of healthy controls, and the intergroup difference was statistically highly significant $(p<0.001)$ (Table 2, Figures 1A and 1B).

\section{Sensitivity and Specificity Analysis}

Using the ROC curve, the AUC for GFAP was 0.903 , which represented a statistically highly 


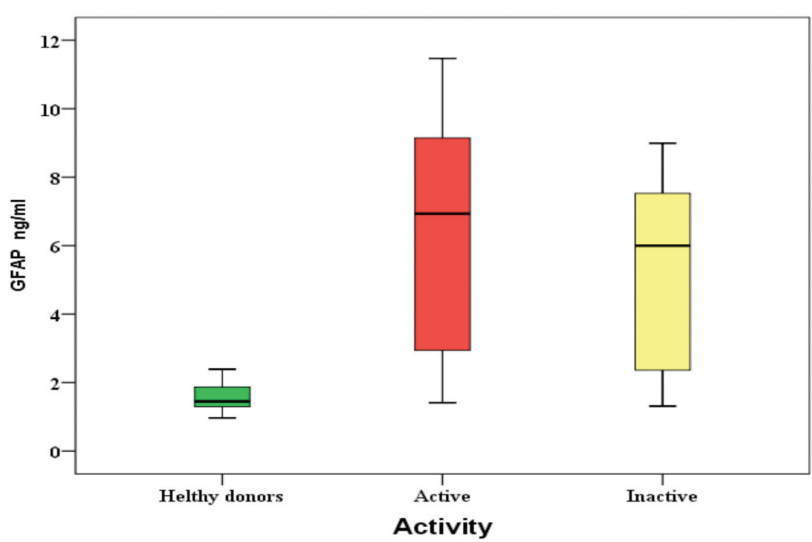

Figure 1-A. A comparison of serum concentrations of GFAP (ng/mL) in RRMS patients and healthy individuals.

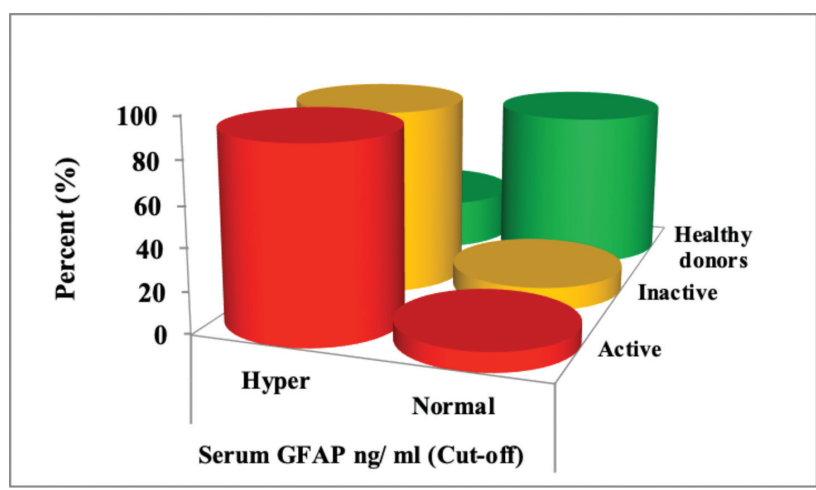

Figure 1-B. Distributions of serum concentrations of GFAP (ng/mL) determined using the ELISA technique, according to studied groups.

significant difference $(p=0.0001)$. The sensitivity (1-false negative \%) and specificity (1-false positive \%) at the cut-off value of $1.89 \mathrm{ng} / \mathrm{mL}$ were $90 \%$ and $76 \%$, respectively. The PPV was $81.8 \%$, the NPV was $86.4 \%$ and the accuracy of the ELISA test was $83.6 \%$ (Figure 2 ).

\section{DISCUSSION}

MS, an inflammatory demyelinating disorder of the CNS that causes significant neurological dysfunction, is characterized by the presence of disseminated lesions in various parts of the brain that develop over time ${ }^{14}$. These lesions are made up of edematous plaques of hypertrophic astrocytes that show dense infiltrates of immune cells and myelin degradation products. During the inactive phase, the lesions are completely demyelinated and hypocellular, and are made up mainly of as-

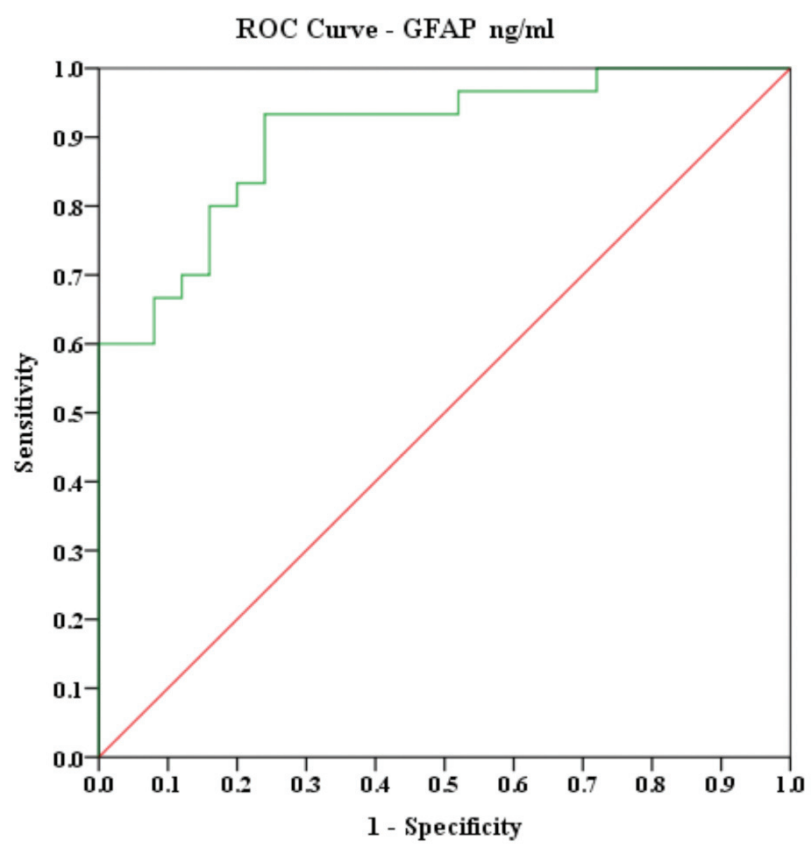

Figure 2. Cut-off value of the serum GFAP concentration (ng/mL) estimated using ELISA to differentiate between patients and healthy controls, according to the ROC curve test.

trocytes ${ }^{15}$. This pathology can be accompanied by symptomatic remission seen in patients presenting with the relapsing-remitting course of the disease $^{16}$. The activity of the disease in MS has been classically defined by the existence of new neurological symptoms and the frequency of relapses. The definition of disease activity has become more accurate with the use of clinical markers, evaluation of ambulation, dexterity, and cognitive functions. Furthermore, Magnetic Resonance Imaging (MRI) has become a vital technique in investigating disease activity ${ }^{17}$. MS biomarkers are safe, measurable, and easy to detect and above all, they are noninvasive methods performed using blood samples. At present, promising biomarkers help in MS diagnosis and prognosis, and they are used to evaluate the response to treatment and suspected side effects ${ }^{18,19}$.

GFAP, an important acidic protein secreted by astrocytes, plays a vital role in several CNS functions and is primarily involved with intake through the blood-brain barrier and maintenance of the cytoskeleton. It has been used as a biochemical 
marker of neurological damage in adults who have suffered strokes and traumatic brain injuries. CNS injury and the consequent compromise of the blood-brain barrier causes the GFAP release into the bloodstream, and so the presence of GFAP in the blood can indicate CNS injury. For example, elevated serum and CSF levels of GFAP have been detected in patients with neuromyelitis optica $(\mathrm{NMO})^{20,21}$. Therefore, it will be important to create a highly sensitive and specific test to provide a faster and more reliable diagnosis providing the advantage of starting treatment earlier.

Storoni et al. ${ }^{22}$ testified an increase in the serum levels of GFAP from $3.2 \mathrm{pg} / \mathrm{mL}$ in patients with inactive MS during remission to $5 \mathrm{pg} / \mathrm{mL}$ and relapse to the active form of the disease. Similar findings were found by Kassubek et al. ${ }^{23}$ who reported GFAP levels in RRMS were significantly higher relative to the controls. A highly significant correlation was observed between GFAP levels and gadolinium enhancement intensity as a marker of an acute exacerbation of the inflammatory processes. Several studies reported correlations between MS severity and the degree of neuronal inflammation in relation to progression of the disease ${ }^{24-26}$.

The composition of CSF is close to that of serum, albeit with slightly different electrolyte levels and considerably lower protein concentration ${ }^{27}$. Recent studies have accurately determined the levels of proteins particularly cytokines including chemokine in both serum and CSF using an ELISA-like method, indicating that such tests can be used with both sample types ${ }^{28}$. Although diagnostic laboratory tests in CSF were only recently standardized, they are now sufficiently accurate to contribute to the diagnosis of conditions that compromise the blood-brain barrier, including MS and Alzheimer's disease ${ }^{29,30}$. The current thinking is that the pathophysiologic mechanism of MS is related to a neurodegenerative process that triggers an inflammatory response. Autopsies have revealed that GFAP levels are considerably raised in the cortices of patients suffering from MS than those observed in controls ${ }^{24}$.

The findings of our study have illustrated that serum GFAP levels were significantly higher amongst RRMS patients than the healthy individuals with statistically significant intergroup differences. Patients with the RRMS in active phase also had higher levels of the protein than those in remission without any statistically significant intergroup difference. These results suggest that the serum GFAP levels may theoretically have a weak potential as a biomarker for active RRMS, but further larger-scale studies with different types of MS using CSF samples could yield more conclusive results.

Our study has also some limitations. One of the main limitations is its small sample size consisting of 58 patients of whom only 22 patients were diagnosed with active RRMS. It is possible that our findings could not be considered specific for all clinical types of MS but they might be specific for all inflammatory processes of the CNS in general. Another limitation is that not all patients have complete data sets apart from neuroimaging. A further limitation is the use of blood samples for testing GFAP instead of CSF samples, although the latter requires an invasive method. Measurement of the biomarkers in blood may not reflect the exact CNS changes associated with low biomarker concentrations as well as diurnal variations. Further studies are needed with larger samples to elucidate roles of GFAP as a parameter in the process of inflammatory diseases of CNS.

\section{REFERENCES}

1. Trapp BD, Nave KA. Multiple sclerosis: an immune or neurodegenerative disorder?. Annu Rev Neurosci. 2008;31:247-69. [CrossRef]

2. Jack C, Ruffini F, Bar-Or A, Antel JP. Microglia and multiple sclerosis. J Neurosci Res. 2005;81(3):363-73. [CrossRef]

3. Petzold A, Michel P, Stock M, Schluep M. Glial and axonal body fluid biomarkers are related to infarct volume, severity, and outcome. J Stroke Cerebrovasc Dis. 2008; 17(4):196-203. [CrossRef]

4. Whitaker JN. Myelin encephalitogenic protein fragments 
in cerebrospinal fluid of persons with multiple sclerosis. Neurology. 1977;27(10):911-20. [CrossRef]

5. Eng LF, Vanderhaeghen JJ, Bignami A, Gerstl B. An acidic protein isolated from fibrous astrocytes. Brain Res. 1971;28(2):351-4. [CrossRef]

6. Missler U, Wiesmann M, Wittmann G, Magerkurth O, Hagenström $\mathrm{H}$. Measurement of glial fibrillary acidic protein in human blood: analytical method and preliminary clinical results. Clin Chem. 1999;45(1):138-41. [CrossRef]

7. Lei J, Gao G, Feng J, et al. Glial fibrillary acidic protein as a biomarker in severe traumatic brain injury patients: a prospective cohort study. Crit Care. 2015;19:362. Published 2015 Oct 12. [CrossRef]

8. Mouser PE, Head E, Ha KH, Rohn TT. Caspase-mediated cleavage of glial fibrillary acidic protein within degenerating astrocytes of the Alzheimer's disease brain. Am J Pathol. 2006;168(3):936-46. [CrossRef]

9. Mokuno K, Kamholz J, Behrman T, et al. Neuronal modulation of Schwann cell glial fibrillary acidic protein (GFAP). J Neurosci Res. 1989;23(4):396-405. [CrossRef]

10. Martínez MA, Olsson B, Bau L, et al. Glial and neuronal markers in cerebrospinal fluid predict progression in multiple sclerosis. Mult Scler. 2015;21(5):550-61. [CrossRef]

11. Huang XJ, Glushakova O, Mondello S, Van K, Hayes RL, Lyeth BG. Acute Temporal Profiles of Serum Levels of UCH-L1 and GFAP and Relationships to Neuronal and Astroglial Pathology following Traumatic Brain Injury in Rats. J Neurotrauma. 2015;32(16):1179-89. [CrossRef]

12. Consortium of MS Centers, MRI Protocol And Clinical Guidelines For The Diagnosis And Follow-Up Of MS. 2018.

13. Lublin FD, Reingold SC. Defining the clinical course of multiple sclerosis: results of an international survey. National Multiple Sclerosis Society (USA) Advisory Committee on Clinical Trials of New Agents in Multiple Sclerosis. Neurology. 1996;46(4):907-11. [CrossRef]

14. Slimp J. Neurophysiology of Multiple Sclerosis. In: Giesser BS (ed). Primer on Multiple Sclerosis, $2^{\text {nd }}$ edition: Oxford University Press; 2016. [CrossRef]

15. Amor S, van der Valk P. Neuropathology of multiple sclerosis. In: Weiner, H.L and Stankiewicz, J.M. (eds.) Multiple Sclerosis - diagnosis and therapy Wiley-Blackwell 2012.

16. Popescu BF, Pirko I, Lucchinetti CF. Pathology of multiple sclerosis: where do we stand?. Continuum (Minneap Minn). 2013;19(4 Multiple Sclerosis):901-21. [CrossRef]

17. Kaunzner UW, Al-Kawaz M, Gauthier SA. Defining Disease Activity and Response to Therapy in MS. Curr Treat Options Neurol. 2017;19(5):20. [CrossRef]
18. Ziemssen T, Akgün K, Brück W. Molecular biomarkers in multiple sclerosis. J Neuroinflammation. 2019;16(1):272. Published 2019 Dec 23. [CrossRef]

19. Al Gawwam G, Sharquie IK. Serum Glutamate Is a Predictor for the Diagnosis of Multiple Sclerosis. ScientificWorldJournal. 2017;2017:9320802. [CrossRef]

20. Marchi N, Rasmussen P, Kapural M, et al. Peripheral markers of brain damage and blood-brain barrier dysfunction. Restor Neurol Neurosci. 2003;21(3-4):109-21.

21. Misu T, Takano R, Fujihara K, Takahashi T, Sato S, Itoyama Y. Marked increase in cerebrospinal fluid glial fibrillar acidic protein in neuromyelitis optica: an astrocytic damage marker. J Neurol Neurosurg Psychiatry. 2009;80(5):575-7. [CrossRef]

22. Storoni M, Verbeek MM, Illes Z, et al. Serum GFAP levels in optic neuropathies. J Neurol Sci. 2012;317(1-2):11722. [CrossRef]

23. Kassubek R, Gorges $M$, Schocke $M$, et al. GFAP in early multiple sclerosis: A biomarker for inflammation. Neurosci Lett. 2017;657:166-70. [CrossRef]

24. Petzold A, Eikelenboom MJ, Gveric D, et al. Markers for different glial cell responses in multiple sclerosis: clinical and pathological correlations. Brain. 2002;125(Pt 7):1462-73. [CrossRef]

25. Axelsson M, Malmeström C, Nilsson S, Haghighi S, Rosengren L, Lycke J. Glial fibrillary acidic protein: a potential biomarker for progression in multiple sclerosis. J Neurol. 2011;258(5):882-8. [CrossRef]

26. Mañé-Martínez MA, Olsson B, Bau L, et al. Glial and neuronal markers in cerebrospinal fluid in different types of multiple sclerosis. J Neuroimmunol. 2016;299:112-7. [CrossRef]

27. Matsumae M, Sato O, Hirayama A, et al. Research into the Physiology of Cerebrospinal Fluid Reaches a New Horizon: Intimate Exchange between Cerebrospinal Fluid and Interstitial Fluid May Contribute to Maintenance of Homeostasis in the Central Nervous System [published correction appears in Neurol Med Chir (Tokyo). 2018;58(5):228]. Neurol Med Chir (Tokyo). 2016;56(7):416-41. [CrossRef]

28. Hofer LS, Mariotto S, Wurth S, et al. Distinct serum and cerebrospinal fluid cytokine and chemokine profiles in autoantibody-associated demyelinating diseases. Mult Scler J Exp Transl Clin. 2019;5(2):2055217319848463. [CrossRef]

29. Algotsson A, Winblad B. The integrity of the bloodbrain barrier in Alzheimer's disease. Acta Neurol Scand. 2007;115(6):403-8. [CrossRef]

30. Luque FA, Jaffe SL. Cerebrospinal fluid analysis in multiple sclerosis. Int Rev Neurobiol. 2007;79:341-56. [CrossRef] 